\title{
PENGGUNAAN PANDUAN TEKNIK SELF INSTRUCTION SEBAGAI MEDIA UNTUK MENINGKATKAN DISIPLIN DIRI SISWA SMA
}

\author{
Rosalia Dewi Nawantara', Laelatul Arofah², Nora Yuniar Setyaputri ${ }^{3}$ \\ Universitas Nusantara PGRI Kediri 1,2,3 \\ rosaliadewi@unpkediri.ac.id, laelatularofah@unpkediri.ac.id, setyaputrinora@gmail.com
}

\begin{abstract}
Self-discipline is an important attribute that must be possessed by students. The reality at school is that there are students who have low self-discipline. Low self-discipline is characterized by behavior that violates the rules of school until arriving late to school, not using the complete school attributes, and some other violiations. This phenomenon should be of particular concern because low of self-discipline will affect the academic field of students. One technique in counseling services that can be used to improve selfdiscipline is self instruction technique. Self-instruction techniques focus on positive selfwords that can control behavior. The self instruction technique in this research was applied through the media guide. The purpose of this study is to improve the selfdiscipline of high school students through self-instruction technical guidance. The research method used was an experimental one type pretest-posttest design. The population of this research is the XI grade students of SMAN 1 Srengat. The sampling technique used was purposive sampling. The data collection instrument used was a scale of self-discipline. Data results from these instruments were analyzed using paired sample tests with the help of SPSS for windows with a significance value of $0.004<0.05$. This means that there are differences in the level of student self-discipline before and after the self instruction technique guide is given. The difference shows that the self instruction technique guide is effective for improving the self-discipline of high school students.
\end{abstract}

\section{ABSTRAK}

Self discipline atau disiplin diri adalah atribut diri yang perlu dimiliki oleh siswa. Fenomena nyata di sekolah menunjukkan masih terdapat siswa yang memiliki disiplin diri rendah. Disiplin diri rendah ditandai dengan perilaku melanggar peraturan sekolah sampai di sekolah terlambat, menggunakan atribut sekolah yang tidak lengkap, dan lain sebagainya. Fenomena tersebut hendaknya menjadi perhatian khusus karena disiplin diri apabila dibiarkan akan berpengaruh pada bidang akademik siswa. Teknik self instruction merupakan salah satu teknik konseling yang dapat digunakan untuk meningkatkan disiplin diri tersebut. Teknik ini memfokuskan pada kata diri positif yang dapat mengontrol perilaku. Teknik self instruction pada riset ini diterapkan melalui media panduan. Tujuan riset ini adalah untuk meningkatkan disiplin diri siswa Sekolah Menengah Atas melalui panduan teknik self instruction. Metode penelitian yang digunakan adalah eksperimen dengan jenis one group pretest-posttest design. Populasi penelitian ini adalah siswa kelas XI SMAN 1 Srengat. Purposive samplingmerupakan teknik mengambilan sampel yang dipakai dalam peneltian ini. Instrumen yang digunakan adalah skala disiplin diri. Hasil data dari instrumen tersebut dianalisis menggunakan paired sample test dengan ketentuannilai signifikansi $0,004<0,05$. Hal tersebut berarti terdapat perbedaan tingkat disiplin diri siswa sebelum dan sesudah diberikan intervensi.Dengan hasil tersebut dapat disimpulkan bahwa bahwa panduan teknik self instruction efektif untuk meningkatkan disiplin diri siswa SMA.
Keywords:

guideline, self instruction technique, self discipline

Kata Kunci: panduan, teknik self instruction, disiplin diri 
Cara mengutip: Nawantara, R. D., Arofah, L., \& Setyaputri, N. Y. (2019). Penggunaan Panduan Teknik Self Instruction Sebagai Media untuk Meningkatkan Disiplin Diri Siswa SMA. Nusantara of Research : Jurnal HasilHasil Penelitian Universitas Nusantara PGRI Kediri (e-Journal), 6(2), 88-94.

https://doi.org/10.29407/nor.v6i2.13609

\section{PENDAHULUAN}

Fenomena mengenai disiplin diri adalah perilaku yang lazim dilakukan oleh pelajar. Dalam lingkup sekolah, masalah mengenai disiplin diri ditunjukkan siswa dengan perilaku membolos saat jam pelajaran, memakai atribut sekolah tidak lengkap, dan terlambat saat datang ke sekolah. Masalah disiplin diri tersebut akan menjadi perilaku maldaptif yang dapat mempengaruhi aktivitas belajar di sekolah jika tidak diberikan intervensi khusus terkait hal tersebut. Berdasarkan studi pendahuluan yang dilakukan oleh Arofah (2017) diperoleh bahwa pelanggaran disiplin diri akademik yang sering dijumpai antara lain beberapa siswa seringkali datang terlambat, merusak sarana prasarana yang ada di sekolah, menunda-nunda dalam mengerjakan tugas serta menyontek saat ulangan berlangsung. Hal tersebut didukung dengan data dari observasi yang dilakukan di SMAN 1 Srengat diketahui bahwa terdapat beberapa perilaku yang menunjukkan rendahnya disiplin diri yaitu beberapa siswa yang terlambat masuk sekolah, melanggar peraturan sekolah seperti memakai atribut sekolah tidak lengkap.

Disiplin diri dapat dideskripsikan sebagai sikap yang sangat diperlukan seorang siswa. Sikap tersebut dapat digunakan siswa untuk mengontrol perilaku mereka khususnya yang berkaitan dengan kegiatan di sekolah. Bryant (2011) menjelaskan bahwa disiplin diri bukan sebuah karakter yang dimiliki atau tidak dimiliki seseorang, bukan sebuah tindakan yang memaksakan diri sendiri melawan dirinya untuk bertindak menggunakan kekuatannya, melainkan sebuah kemampuan yang dapat dipelajari, sadar terhadap setiap tindakan yang berasal dari dalam diri yang kemudian dapat bertanggungjawab terhadap tindakannya. Hal tersebut senada dengan yang diungkapkan Ramli (1999) bahwa disiplin diri merupakan sebuah kapasitas untuk menunjukkan rasa tanggung jawab. Artinya bahwa disiplin diri seseorang ditunjukkan dengan bentuk self direction (pengarahan diri) dan bukan pengarahan orang lain. Disiplin diri juga merupakan proses mengkoordinasikan unsur-unsur jiwa yang bermula dari dalam diri secara sadar. Prijosaksono \& Sanjaya (dalam Fauzan: 2013) juga menjelaskan bahwa disiplin diri sebagai proses melatih diri melakukan segala sesuatu dengan tertib dan teratur secara berkesinambungan untuk meraih impian dan tujuan yang ingin dicapai dalam hidup. Dari pernyataan tersebut dapat ditarik makna bahwa disiplin diri dapat ditumbuhkan serta dikembangkan karena bukan bersifat stagnan.

Faktor pemicu munculnya masalah disiplin diri adalah pikiran disfungsional. Pikiran disfungsional adalah pikiran yang bisa memunculkan perasaan/emosi tertentu, yang akhirnya diikuti oleh perilaku atau tindakan yang selaras dengan pikiran dan perasaan yang muncul (Susana, 2015). Setiap individu diharapkan memiliki disiplin diri, seperti yang diungkapkan Brooks \& Goldstein (2008) bahwa dengan memiliki disiplin diri dan menggunakannya secara efektif akan membuka kesuksesan pada usia dewasa. Oleh karena itu, diperlukan bantuan bagi siswa untuk dapat menguasai disiplin diri. Teknik konseling yang dapat digunakan untuk meningkatkan disiplin diri adalah teknik self instruction. Teknik self instruction masuk pada Cognitive Behavior Modification (CBM). Menurut Meichenbaum (dalam Nawantara, 2015) untuk 
memahami suatu peristiwa kognitif dan terjadinya suatu perilaku diperlukan perhatian khusus pada pidato batin atau dialog diri (self talk). Meichenbaum (dalam Nawantara, 2015) juga memaparkan bahwa inti dari teknik self instruction adalah mengembangkan kontrol diri. Melalui teknik self instruction konseli dapat mengontrol dirinya dalam berpikir serta bertindak dengan memiliki verbalisasi diri yang positif.

Teknik self instruction berisi tahap-tahap yang akan lebih maksimal apabila dilaksanakan menggunakan media BK. Buku panduan adalah media BK yang dipilih untuk mengoperasionalkan teknik self instruction tersebut. Media BK berupa buku panduan ini merupakan media yang dapat digunakan Guru BK dalam pelakasanan layanan BK. Teknik self instruction memerlukan media untuk membantu praktisi mengoperasionalkan teknik tersebut. Jadi, setiap proses pengubahan yang terjadi pada siswa benar-benar terjadi karena telah mengikuti layanan yang difasilitatori oleh Guru BK tersebut. Buku panduan yang dipilih sebagai media dalam penelitian ini merupakan panduan cetak yang didesain secara menarik dan disesuaikan dengan tahapan teknik self instruction. Diharapkan melalui panduan tersebut Guru BK dapat terbantu dalam melaksanakan teknik self instruction untuk meningkatkan disiplin diri siswa SMA.

\section{METODE}

Pendekatan yang digunakan di dalam penelitian ini adalah eksperimen. Pendekatan penelitian eksperimen adalah pendekatan penelitian yang menguji apakah variabel independent dapat mempengaruhi variabel dependent (Cresswell, 2012). Teknik penelitian eksperimen adalah penelitian yang didalamnya terdapat suatu intervensi dan pengukuran sebelum dan setelah diberikan intervensi. Variabel independent di dalam penelitian ini adalah panduan teknik self instruction dan variabel dependent adalah disiplin diri siswa SMA.Pendekatan ini dipilih karena ingin mengetahui apakah ada peningkatan disiplin diri siswa SMA sebelum dan sesudah diberikan konselingkelompok dengan panduanteknik self instruction. Secara khusus teknik eksperimen yang digunakan dalam penelitian ini adalah preeksperimen dengan jenis one group pretest-posttest design. Pre-eksperimen belum merupakan eksperimen sungguh-sungguh karena terdapat variabel lain yang ikut berpengaruh terhadap terbentuknya variabel dependent (Sugiyono, 2008). Adapun gambar desain dapat dilihat sebagai berikut.

\begin{tabular}{|c|c|}
\hline $\mathrm{O}_{1}$ & $x$ \\
\hline
\end{tabular}

Gambar 3.1 one group pretest-posttest design (Sugiyono, 2008)

Keterangan:

01: pelaksanaan pretest

$\mathrm{X}$ : intervensi/ treatment

O2: pelaksanaan posttest

Tahapan dalam penelitian ini antara lain pelaksanaan pretest, pelaksanaan treatment, dan pelaksanaan posttest. Dalam tahap pelaksanaan pretest, akan didapatkan data tentang tingkat disiplin diri siswa SMA. Pengumpulan data dengan menggunakan skala pengukuran 
disiplin diri siswa. Setelah dilaksanakan pretest maka dilakukan konseling kelompok menggunakan panduan teknik self instruction. Dalam pelaksanaan posttets, akan didapat hasil dari setelah perlakuan. Pengumpulan data posttest menggunakan skala pengukuran disiplin diri siswa.

Penelitian ini dilaksanakan di SMAN 1 Srengat selama 8 bulan, yakni antara bulan Februari sampai Oktober 2019.Subjek penelitian yang dipakai adalah siswa kelas XI IPS berjumlah 8 siswa yang menunjukkan tingkat disiplin diri rendah. Subjek penelitian dipilih dengan menggunakan teknik purposive sampling. Teknik ini dipilih dengan pertimbangan penelitian dilaksanakan pada siswa kelas XI yang memiliki tingkat disiplin diri rendah.

Instrumen pengumpulan datayang digunakan untuk mendapatkan data mengenai tingkat disiplin diri siswaadalah skala disiplin diri. Skala pengukuran disiplin diri siswa ini akan ditransformasikan berupa angka (simbol kuantitatif) dengan memberikan skor dalam setiap pilihan jawaban. Uji analisis data dilakukan dengan menggunakan Paired Sample T-test dengan bantuan program SPSS IBM Statistic 20.0. Pengujian ini menggunakan ketentuan sebagai berikut: 1) apabila signifikansi $>0,05$ maka $\mathrm{H}_{\mathrm{O}}$ diterima dan 2) apabila signifikansi $<0,05$ maka $\mathrm{H}_{\mathrm{O}}$ ditolak.

\section{HASIL}

Dalam hasil penelitian ini akan dijelaskan data statistic deskriptif dari kegiatan pretest dan posttest serta hasil analisis data menggunakan paired sample test.

Tabel 1.1. Statistik Deskriptif Hasil Pretest dan Posttest

Descriptive Statistics

\begin{tabular}{lrrrrrr}
\hline & N & Minimum & Maximum & Mean & Std. Deviation & Variance \\
\hline PRETEST & 8 & 125 & 151 & 143.88 & 9.658 & 93.268 \\
\hline POSTTEST & 8 & 137 & 181 & 160.5 & 13.533 & 183.143 \\
\hline Valid N (listwise) & 8 & & & & &
\end{tabular}

Dari tabel 1.1. didapatkan statistic deskriptif dari hasil pretest dan posttest skala disiplin diri siswa. Pada kegiatan pretest didapatkan nilai mean sebesar 143,88 dengan standar deviasi 9,658. Pada kegoatan posttest didapatkan nilai mean sebesar 160,5 dengan standar deviasi 13,533. Setelah dihitung statistic deskriptif dari nilai prestest dan posttest, maka dilakukan uji prasyarat berupa tes normalitas dan tes homogenitas untuk menentukan apakah uji hipotesis menggunakan statistic parametric dan non parametric. Uji normalitas dan uji homogenitas dijelaskan pada tabel 1.2. dan tabel 1.3.

Tabel 1.2. Uji Normalitas Data Pretest dan Posttest

\begin{tabular}{|c|c|c|c|c|c|c|c|c|}
\hline \multicolumn{9}{|c|}{ Tests of Normality } \\
\hline & Kolmogorov-Smirnova & & & & Shapiro- & & & \\
\hline & Statistic & & $d f$ & Sig. & Statistic & & df & Sig. \\
\hline PRETEST & & 0.327 & 8 & 0.012 & & 0.752 & 8 & 0.009 \\
\hline POSTTEST & & 0.191 & 8 & $.200^{*}$ & & 0.969 & 8 & 0.893 \\
\hline
\end{tabular}

* This is a lower bound of the true significance.

a Lilliefors Significance Correction 
Tabel 1.2 menunjukkan hasil uji normalitas data pretest dan posttest. Nilai signifikansi data pretest menurut Kolmogorov-Smirnov pada masing-masing kelompok adalah 0,012 yaitu $<0,05$ sehingga data berdistribusi tidak normal. Nilai signifikansi posttest pada masing-masing kelompok adalah 0,200yaitu $>0,05$. Hal tersebut berarti data posttest memiliki distribusi normal.

Tabel 1.3. Uji Homogenitas Data Pretest dan Posttest

\begin{tabular}{lllll}
\hline \multicolumn{5}{c}{ Test of Homogeneity of Variances } \\
\hline PREPOST & & & \\
\hline Levene Statistic & df1 & df2 & Sig. \\
\hline 0.602 & 1 & 14 & 0.451 \\
\hline
\end{tabular}

Tabel 1.3. menunjukkan hasil uji homogenitas data prepost atau pretest dan posttest menunjukkan nilai signifikansi $0,451 \quad(>0,05)$, sehingga varian dalam kelompok-kelompok sampel adalah sama atau homogen. Setelah uji normalitas dan uji homogenitas maka langkah selanjutnya menguji hipotesis penelitian. Dalam penelitian ini terdapat dua hipotesis penelitian yaitu:

$\mathrm{H}_{1}$ : Terdapat perbedaan tingkat disiplin diri siswa sebelum dan sesudah diberikan panduan teknik self instruction.

$\mathrm{H}_{\mathrm{O}}$ : Tidak terdapat perbedaan tingkat disiplin diri siswa sebelum dan sesudah diberikan panduan teknik self instruction. test.

Uji hipotesis dalam penelitian ini menggunakan uji beda (parametrik) yaitu paired sample

Tabel 1.4. Uji Analisis Data Paired Sample Test

\begin{tabular}{|c|c|c|c|c|c|c|c|c|c|}
\hline \multicolumn{10}{|c|}{ Paired Samples Test } \\
\hline & & \multicolumn{5}{|c|}{ Paired Differences } & \multirow{3}{*}{$\mathrm{t}$} & \multirow{3}{*}{ df } & \multirow{3}{*}{$\begin{array}{l}\text { Sig. (2- } \\
\text { tailed) }\end{array}$} \\
\hline & & & & $\begin{array}{l}\text { Std. } \\
\text { Error }\end{array}$ & $\begin{array}{r}95 \% \text { Con } \\
\text { Interval } \\
\text { Differ }\end{array}$ & $\begin{array}{l}\text { idence } \\
\text { of the } \\
\text { nce }\end{array}$ & & & \\
\hline \multirow{2}{*}{$\begin{array}{c}\text { Pair } \\
1\end{array}$} & \multirow{2}{*}{$\begin{array}{c}\text { POSTTEST - } \\
\text { PRETEST }\end{array}$} & Mean & Deviation & Mean & Lower & Upper & & & \\
\hline & & 16.625 & 11.363 & 4.018 & 7.125 & 26.125 & 4.138 & 7 & 0.004 \\
\hline
\end{tabular}

Dari hasil uji paired sample test menunjukka nilai signifikansi sebesar 0,004 dimana

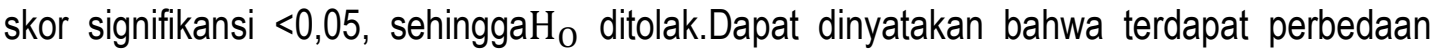
tingkat disiplin diri siswa sebelum dan sesudah diberikan panduan teknik self instruction.

\section{PEMBAHASAN}

Dari hasil uji hipotesis diperoleh bahwa terdapat perbedaan tingkat disiplin diri siswa sebelum dan sesudah diberikan panduan teknik self instruction. Hasil tersebut menunjukkan bahwa penggunaan panduan teknik self instruction sebagai media untuk meningkatkan disiplin diri siswa SMA terbukti efektif.

Teknik self instruction merupakan salah satu teknik dari pendekatan cognitive behavioral therapy menggunakan kontrol verbal yang dapat memengaruhi perilaku motorik. Perilaku disiplin diri adalah kemampuan seseorang dalam mengatur, mengarahkan, dan 
mengontrol perilaku (Bryant, 2011). Sehingga teknik self instruction dipandang mampu membantu siswa dalam meningkatkan disiplin dirinya.

Teknik self instruction merupakan suatu teknik yang tidak hanya dilaksanakan sebagai suatu deskripsi saja tetapi juga bertujuan mengajarkan suatu keterampilan pada diri individu. Oleh karena itu, teknik self instruction dipandang sangat ideal untuk diaplikasikan dalam bentuk media BK yaitu panduan.

Didalam panduan teknik self instruction berisi tasks atau tugas-tugas untuk konseli yang dapat menjadi panduan konselor atau guru BK. Instruksi dalam panduan teknik self instruction juga dirasa sangat jelas dan dapat dipahami. Hal tersebut telah dijelaskan dalam penelitian sebelumnya oleh Nawantara (2019) yang berjudul Pengembangan Panduan Konseling Kelompok Dengan Teknik Self instruction Untuk Meningkatkan Disiplin Diri Siswa SMA Kota Kediri. Dimana dalam penelitian tersebut panduan teknik self instruction dapat diterima secara teoritis dan praktis dilihat dari uji ahli materi, media, dan uji pengguna produk.

Panduan teknik self instruction berisi tentang penguraian kembali persepsi siswa terhadap sikap disiplin diri itu sendiri. Dalam pertemuan pertama dalam panduan akan diidentifikasi bagaimana persepsi (pikiran) siswa yang berdampak pada perilaku dan perasaannya. Selanjutnya siswa diajak untuk mengidentifikasi kembali apakah hal-hal tersebut memicu negative self talk dalam diri mereka. Apabila siswa menemukan negative self talk dalam menghadapi masalah terkait disiplin diri selanjutnya guru BK segera mengajak untuk menggantinya dengan positive self talk. Setelah itu siswa diminta untuk mengikuti tahapanself guidance yang berisi tentang bagaimana siswa dapat membimbing dirinya sendiri menggunakan positive self talk yang telah diidentifikasi sebelumnya. Melalui tahapan tersebut, siswa belajar untuk dapat melafalkan positive self talk terkait disiplin diri dengan covert dan overt speech. Di akhir self guidance, siswa diarahkan untuk dapat memberikan motivasi kepada dirinya sendiri terkait usahanya untuk dapat menumbuhkan positive self talk terkait disiplin diri yang telah ia lakukan.

\section{KESIMPULAN DAN SARAN}

Kesimpulan penelitian ini menunjukkan bahwa terdapat perbedaan tingkat disiplin diri siswa sebelum dan sesudah diberikan panduan teknik self instruction. Saran untuk penelitian ini adalah diharapkan bagi peneliti selanjutnya untuk dapat meneliti variabel yang sama dengan subjek yang lebih luas misalkan pada siswa sekolah menengah kejuruan atau bahkan mahasiswa pendidikan tinggi.

\section{DAFTAR RUJUKAN}

Arofah, L. 2017. Pentingnya Siswa Memiliki Self Discipline Sebagai Alternatif Penguatan Karakter. Seminar Nasional Peran Bimbingan dan Kosneling dalam Penguatan Pendidikan Karakter.Jogjakarta: Universitas Ahmad Dahlan.

Brooks, R. \& Goldstein, S. 2008. Raising A Self Disciplined Child. United States: Mc Graw Hill.

Bryant, T. 2011. Self Discipline in 10 days: How to Go from Thinking to Doing. Seattle, Washington: Human Understanding and Behavior Publishing. 
Creswell, J.W. 2012. Educational Research: Planning, Conducting, and Evaluating Quantitative and Qualitative Research. 4th Edition. Boston: Pearson.

Fauzan, L. 2013. Self Discipline Siswa Sebagai Masalah dalam Bimbingan dan Konseling: Gambaran dan Model Bantuannya. Jurnal Kajian Teori dan Praktik Kependidikan, 1 (40): 16-23.

Nawantara, R. D. 2015. Perbedaan Komitmen Tugas Siswa SMP Negeri 4 Malang Melalui Penerapan Teknik Reframing dan Self Instruction. Tesis tidak Diterbitkan: Pascasarjana Universitas Negeri Malang.

Nawantara, R. D., Arofah, L., Setyaputri, N.Y. 2019. Development of Self Instruction Technical Guidelines to Improve High School Students's Self Discipline. The 3rd International Conference on Education Innovation (ICEI) dengan tema "Empowering Education in Society 5.0 Era". Surabaya: Faculty of Education, State University of Surabaya.

Ramli, M. 1999. Developing Student Self Discipline. Jurnal Filsafat, Teori, dan Praktik Kependidikan, $26: 12-21$.

Sugiyono. 2008. Metode Penelitian Kuantitatif, Kualitatif, dan R\&D. Bandung: Alfabeta.

Susana, T., Parmadi, E. H., \& Adi, P. S. 2015. Program Bantu Diri Terapi Kognitif Perilaku: Harapan bagi Penderita Depresi. Jurnal Psikologi, Vol. 42 (1): 78-98. 